


Jurnal Etika Demokrasi

Vol 4 Januari No. 12019

\title{
Pengaruh Pembelajaran PPKn Berbasis Discovery Learning terhadap Hasil Belajar pada Siswa Kelas X IPA Batara Gowa
}

\author{
Rismawati ${ }^{1)}$, Mardiana $^{2)}$ \& Syamsir ${ }^{3)}$ \\ Pendidikan Pancasila dan Kewarganegaraan FKIP Universitas Muhammadiyah Makassar ${ }^{1)}$ \\ Pendidikan Pancasila dan Kewarganegaraan FKIP Universitas Muhammadiyah Makassar ${ }^{2)}$ \\ Pendidikan Pancasila dan Kewarganegaraan FKIP Universitas Muhammadiyah Makassar ${ }^{3)}$ \\ rismawati@unismuh.ac.id ${ }^{1)}$ mardiana@unismuh.ac.id ${ }^{2}$ )
}

\begin{abstract}
The problems in this study are (1) What is the PPKn Learning Process in Gowa Batara High School? and (2) Is there any influence of Discovery Learning-Based PPKn learning on learning outcomes in high school students of class X IPA Batara Gowa ?. This study aims at (1) to find out the PPKn learning process in class X of Batara Gowa High School Science and (2) to determine the effect of PPKn learning based on Discovery Learning on learning outcomes of class X IPA SMA Batara Gowa students. The research method used in this study is an experimental method with a form of research, which is a quasi-experimental (quasi experimental design) and a research design that is used is a technique of collecting data in the form of observation and learning outcomes. The data analysis technique used is the technique of analyzing the data of test results and questionnaires. The results of this study indicate that the Discovery Learning learning model can be improved on the learning outcomes of students in Batara Gowa High School Science $X$ class based on the calculation of pretest and posttest test data analysis using $t$ count $X, Y, d$, and $d 2$, namely the total $X$ value of $1.130 \%$ and the average value of $51.36 \%$. While the value of $Y$ is $1.560 \%$, with an average value of $70.90 \%$. For the value of $d$ with the amount of 420 with an average value of 19.09 and for the value of $d 2$ with the number $12,200 \%$ with an average value of $554.54 \%$. So there is an influence on the differences in the average learning outcomes of students who use the Discovery Learning learning model with the average student learning outcomes.
\end{abstract}

Keywords : Learning, Discovery Learning and Student Learning Outcomes

\begin{abstract}
Abstrak. Masalah dalam penelitian ini adalah (1) Bagaimana Proses Pembelajaran PPKn di SMA Batara Gowa? dan (2) Apakah ada pengaruh pembelajaran PPKn Berbasis Discovery Learning terhadap hasil belajar pada siswa kelas $X$ IPA SMA Batara Gowa?. Penelitian ini bertujuan (1) untuk mengetahui proses Pembelajaran PPKn dikelas X IPA SMA Batara Gowa dan (2) untuk mengetahui pengaruh pembelajaran PPKn berbasis Discovery Learning terhadap hasil belajar siswa kelas X IPA SMA Batara Gowa. Metode penelitian yang di gunakan dalam penelitian ini adalah metode eksperimen dengan bentuk penelitian yaitu Eksperimen semu (quasi experimental design) dan rancangan penelitian yang di gunakan adalah teknik pengumpulan data berupa teknik observasi dan tes hasil belajar. Teknik analisis data yang di gunakan adalah teknik analisis data hasil tes dan angket. Hasil penelitian ini menunjukkan bahwa model pembelajaran Discovery Learning dapat meningkat terhadap hasil belajar siswa di kelas X IPA SMA Batara Gowa berdasarkan hasil perhitungan analisis data hasil tes Pretest dan Posttest menggunakan $t$ hitung $X, Y, d$, dan $d^{2}$ yaitu jumlah nilai keseluruhan $X$ sebanyak $1.130 \%$ dan nilai rata-rata sejumlah $51,36 \%$. Sedangkan nilai $Y$ sejumlah $1.560 \%$, dengan nilai rata-rata 70,90\%. Untuk nilai d dengan jumlah 420 dengan nilai rata-rata 19,09 dan Untuk nilai $\mathrm{d}^{2}$ dengan jumlah $12,200 \%$ dengan nilai rata-rata sebanyak $554,54 \%$. Jadi terdapat pengaruh pada perbedaan ratarata hasil belajar siswa yang menggunakan model pembelajaran Discovery Learning dengan rata-rata hasil belajar siswa.
\end{abstract}

Kata kunci: Pembelajaran, Discovery Learning dan Hasil Belajar siswa 


\section{PENDAHULUAN}

Peran dan tanggung jawab seorang pendidik disekolah sangatlah besar dalam mengajar yang merupakan suatu perbuatan memerlukan tanggung jawab moral, sehingga keberhasilan pendidikan siswa secara formal terletak pada tanggung jawab pendidik dalam melaksanakan tugas mengajar. Dengan beraneka ragam karakteristik peserta didik dalam belajar maka penting bagi pendidik memiliki keterampilan mengajar dan kreatif dalam menyampaikan informasi. Hal tersebut sesuai dengan fungsi dan tujuan pendidikan menurut Undang-Undang Nomor 20 tahun 2003 tentang fungsi dan tujuan pendidikan adalah :

Fungsi pendidikan adalah mengembangkan kemampuan dan membentuk watak serta peradaban bangsa yang bermartabat dalam rangka mencerdaskan kehidupan bangsa. Sedangkan tujuan pendidikan adalah untuk mengembangkan potensi peserta didik agar menjadi manusia yang beriman dan bertakwa kepada Tuhan Yang Maha Esa, berakhlak mulia, sehat, berilmu, cakap, kreatif, mandiri, dan menjadi warga Negara yang demokratis serta bertanggung jawab.

Menurut hasil observasi yang dilakukan di SMA Batara Gowa dengan wawancara kepada kepala sekolah, masalah yang ditemukan dilapangan terhadap pembelajaran PPKn adalah kurangnya disiplin siswa dalam proses pembelajaran, seperti siswa sering datang terlambat kesekolah, dalam mengerjakan tugas tidak tepat waktu, kurang mentaati tata tertib disekolah. Sehingga hal tersebut berdampak pada menurunnya hasil belajar siswa. Hal tersebut terbukti pada saat observasi awal yang dilakukan, terlihat dari hasil belajar yang diperoleh siswa sangat kurang maksimal. Banyak ditemukan dalam proses pembelajaran di Sekolah guru masih menggunakan metode ceramah sementara siswa hanya mendengarkan dan mencatat dari papan tulis. Guru belum berupaya maksimal untuk meningkatkan kualitas dan efektifitas pembelajaran di sekolah untuk memperoleh pembelajaran yang maksimal dan bermakna.

Oleh karena itu, disini guru dituntut untuk mengembangkan kegiatan pembelajaran dengan berbagai model dan metode pembelajaran yang dapat mengembangkan kemampuan berpikir siswa. Model pembelajaran digunakan sebagai pedoman untuk melakukan kegiatan belajar mengajar di dalam kelas, model pembelajaran juga berisikan seperangkat konsep yang sistematis yang dapat menunjang kegiatan belajar mengajar sehingga dapat mencapai tujuan tertentu atau tujuan yang telah direncanakan sebelumnya.

Sebuah proses pembelajaran mutlak diperlukan adanya sebuah strategi atau model pembelajaran. Hal ini dimaksudkan agar pembelajaran tidak berlangsung seadanya. Pembelajaran haruslah berlangsung dengan terencana. Melihat masalah diatas, perlu adanya inovasi dalam proses pembelajaran, sehingga tujuan pembelajaran dapat tercapai dengan maksimal. Hal tersebut dapat dilakukan dengan menggunakan model pembelajaran yang sesuai dengan karakter siswa. Salah satu model pembelajaran yang diharapkan mampu mengatasi masalah diatas adalah dengan menggunakan model Discovery Learning.

Untuk mengatasi masalah tersebut, maka perlu dicari model pembelajaran yang tepat, sehingga dapat meningkatkan hasil belajar siswa dalam pembelajaran Pendidikan Kewarganegaraan. Penggunaan model pembelajaran yang baik akan meningkatkan hasil belajar keseluruhan baik ranah kognitif, psikomotorik maupun afektif. Martinis Yamin (2007:82) menegaskan dengan belajar aktif siswa berusaha membangun pengetahuan dalam dirinya sehingga dalam proses pembelajaran terjadi perubahan peningkatan mutu kemampuan, pengetahuan dan keterampilan siswa baik dalam ranah kognitif, psikomotorik dan afektif. Menyadari kenyataan seperti ini, para ahli berupaya untuk mencari dan merumuskan model pembelajaran yang dapat merangkul semua perbedaan yang dimiliki oleh siswa didik. Model pembelajaran yang ditawarkan itu adalah model

Berdasarkan pendapat diatas dapat disimpulkan penerapan Model pembelajaran Discovery Learning pada mata pelajaran PPKn mampu memberikan hasil yang positif terhadap kualitas proses dan hasil belajar Pendidikan 
Kewarganegaraan. Model pembelajaran Discovery Learning dalam pembelajaran PPKn, pada akhirnya juga diharapkan dapat membiasakan peserta didik untuk melakukan proses yang diyakini dapat membuat pembelajaran semakin bermakna.

\section{METODE PENELITIAN}

Penelitian ini merupakan penelitian eksperimen yaitu jenis One-Group Pretest-Posttest Design. Dalam penelitian ini, hasil perlakuan dapat diketahui lebih akurat, karena dapat membandingkan dengan keadaan sebelum diberi perlakuan (treatment).

Penelitian ini dilaksanakan di SMA Batara Gowa. Waktu penelitian ini di laksanakan pada bulan September 2018.

Subyek penelitian adalah Siswa X SMA Batara Gowa tahun pembelajaran 2018 dengan sasaran penelitian, yaitu adanya peningkatan hasil belajar siswa yang dapat dicapai setelah proses belajar mengajar selesai dilaksanakan.

Hasil belajar dalam penelitian ini mencangkup pada ranah kognitif dan ranah afektif. Hasil belajar yang dimaksud dalam penelitian ini adalah kelincahan, ketepatan dan kesesuaian ketika siswa menyelesaikan tugas pada tes awal (pretest) dan menyelesaikan tugas pada tes akhir (posttest).

Langkah Persiapan Model Discovery Learning

1) Menentukan tujuan pembelajaran.

2) Melakukan identifikasi karakteristik siswa (kemampuan awal, minat, gaya belajar, dan sebagainya).

3) Memilih materi pelajaran.

4) Menentukan topik-topik yang harus dipelajari siswa secara induktif (dari contoh-contoh generalisasi).

5) Mengembangkan bahan-bahan belajar yang berupa contoh-contoh, ilustrasi, tugas dan sebagainya untuk dipelajari siswa.

6) Mengatur topik-topik pelajaran dari yang sederhana ke kompleks, dari yang konkret ke abstrak, atau dari tahap enaktif, ikonik sampai ke simbolik.

7) Melakukan penilaian proses dan hasil belajar siswa.
Instrumen yang digunakan untuk menggumpulkan data dalam penelitian ini adalah:

1. Lembar Obsevasi

Instrumen ini dirancang oleh tim peneliti untuk mengumpullkan data mengenai kehadiran dan aktvitas siswa selama proses pembelajaran berlangsung.

2. Tes Hasil Belajar

Instrumen ini disusun oleh peneliti untuk memperoleh informasi tentang penguasaan siswa terhadap materi ajar, setelah proses pembelajaran berlangsung

Teknik pengumpulan data yang digunakan dalam penelitian ini adalah tes awal dan tes akhir, adapun langkah-langkah pengumpulan data yang akan dilakukan sebagai berikut:

1. Observasi. Observasi merupakan "suatu proses yang kompleks, yaitu proses pengamatan dan ingatan. Untuk mendapatkan data yang relevan dalam penelitian ini, maka peneliti menggunakan teknik observasi lansung. Teknik observasi lansung adalah suatu teknik penelitian yang dilakukan dengan mengadakan pengamatan lansung kepada objek-objek dalam penelitian. Observasi ini di lakukan selama peneliti melakukan penelitian di SMA Batara Gowa

2. Tes. Tes awal dilakukan sebelum treatment, pretest dilakukan untuk mengetahui kemampuan yang dimiliki oleh siswa sebelum digunakan metode pembelajaran Discovery Learning. Setelah treatment, tindakan selanjutnya adalah posttest untuk mengetahui pengaruh pembelajaran PKn Dengan model Discovery Learning

Untuk menganalisis data yang diperoleh dari hasil penelitian akan menggunakan Teknik Analisis data Hasil tes. Data yang terkumpul berupa nilai pretest dan nilai posttest.

\section{PEMBAHASAN}

Dalam proses pembelajaran kebanyakan guru hanya menggunakan metode ceramah tak ada guru yang menerapkan model-model pembelajaran seperti model Discovery Learning. Guru hanya menerapkan konsep, memberikan atau menuliskan 
tujuan pembelajaran di papan tulis kemudian di suruh cari referensi melalui media yaitu berupa hp(google) dll. karena di SMA Batara Gowa fasilitas pembelajaran kurang yaitu buku maka siswa di tuntun menggunakan hp atau media untuk memaksimalkan ilmu pengetahuan.

Pada proses pembelajaran para siswa khususnya Kelas X IPA masih ada beberapa siswa yang kurang disiplin dan tidak memperhatikan guru pada saat menjelaskan, ada yang sibuk main $\mathrm{hp}$, ada yang mengobrol, dan mengganggu temannya saat proses pembelajaran, dalam hal ini guru juga menengur beberapa siswa tersebut akan tetapi mereka masih saja tidak memperhatikan apa yang di jelaskan guru didepan kelas. Pada saat guru mengajar, guru menggunakan media seperti spidol, papan tulis, dan buku paket. Hal tersebut menunjukkan bahwa media yang di gunakan guru pada proses pembelajaran masih kurang, sehingga para siswa juga menjadi tidak tertarik, sangat pasif, tidak kreatif dan tidak produktif terhadap pembelajaran yang di lakukan oleh guru.

Discovery Learning adalah suatu rangkaian kegiatan pembelajaran yang melibatkan seluruh kemampuan siswa secara maksimal untuk mencari dan menyelidiki secara sistematis, kritis, dan logis sehingga siswa dapat menemukan sendiri pengetahuan, sikap, dan keterampilan sebagai wujud adanya perubahan tingkah laku.

Discovery learning pembelajaran merupakan cara-cara yang akan dipilih dan digunakan oleh seorang pengajar untuk menyampaikan materi pembelajaran sehingga akan mudah peserta didik menerima dan memahami materi pembelajaran, yang pada akhirnya tujuan kegiatan pembelajaran dapat dikuasainya diakhir kegiatan belajar. Pendekatan pembelajaran merupakan titik tolak atau sudut pandang terhadap proses pembelajaran yang merujuk pada pandangan terjadinya suatu proses yang sifatnya masih sangat umum, yang di dalamnya mewadahi, mengispirasi, menguatkan dan malatri metode pembelajarandengan cakupan teoritis tertentu. Pendekatan pembelajaran ada dua yaitu: pendekatan pembelajaran yang berorientasi atau berpusat kepada peserta didik dan pendekatan pembelajaran yang berorientasi atau berpusat kepada guru. Pendidikan Kewarganegaraan hendaknya menggunakan pendekatan yang berpusat kepada peserta didik.

Berdasarkan hasil penelitian bahwa dengan di terapkannya model pembelajaran Discovery Learning merupakan suatu pembelajaran dimana siswa harus berperan aktif dalam suatu pembelajaran sehingga pembelajaran yang dirancang sedemikian rupa siswa dapat menemukan konsep-konsep dan prinsip-prinsip melalui proses mentalnya sendiri, dan siswa mampu mengetahui sendiri informasi yang sudah mereka miliki merupakan suatu pembelajaran dimana siswa harus berperan aktif dalam suatu pembelajaran sehingga pembelajaran yang dirancang sedemikian rupa siswa dapat menemukan konsep-konsep dan prinsip-prinsip melalui proses mentalnya sendiri, dan siswa mampu mengetahui sendiri informasi yang sudah mereka miliki.

Dalam pelaksaan penelitian tindakan kelas ini yang menerapkan model pembelajaran Discovery Learning yang efektif untuk meningkatkan hasil belajar siswa dengan metode belajar yang sifatnya mandiri dimana siswa yang cenderung lebih aktif untuk mencari dan menemukan informasi melalui bahan ajar.

Dari hasil deskripsi data di atas sebelum peneliti melakukan penelitian terlebih dahulu memberikan Pretest mata pelajaran PPKn pada kelas X IPA untuk mengetahui hasil perbandingan belajar siswa sebelum di terapkan model Discovery Learning. setelah di berikan Pretest selanjutnya peneliti memberikan perlakuan dengan menerapkan model pembelajaran Discovery Learning pada kelas $X$ IPA. Dengan adanya penilaian penugasan Discovery Learning inilah peneliti dapat mengetahui kesistematisikan dan keseriusan siswa dalam mengikuti proses pembelajaran Discovery Learning terdapat hasil yang baik. Selanjutnya tahap akhir dalam penelitian ini adalah siswa di berikan Posttest mata pelajaran PPKn untuk mengetahui hasil belajar setelah di terapkan model Discovery Learning, jawaban soal Posttest siswa di beri nilai dan di hitung rata-rata hasil belajar siswa. Berdasarkan 
rekapitulasi data siswa dapat di ketahui bahwa proses belajar siswa meningkat atau ada perubahan setelah di terapkan model pembelajaran Discovery Learning di SMA Batara Gowa kelas X IPA

Berdasarkan hasil angket respon siswa anda menyukai pelajaran PPKn dari 22 siswa 22 oarang menjawab ya' menurut anda PPKn merupakan mata pelajaran yang mudah dari 22 siswa 15 orang menjawab ya'dan 7 orang yang menjawab tidak, sebelum penelitian ini anda sudah mengetahui pelajaran PPKn menggunakan model pembelajaran Discovery Learning dari 22 siswa 15 orang menjawab ya' dan 7 orang menjawab tidak, Discovery Learning mempermudah anda dalam memahami pembelajaran PPKn dari 22 siswa 16 orang menjawab ya' dan 6 orang menjawab tidak,anda mengalami kesulitan selama pembelajaran PPKn menggunakan model Discovery Learning dari 22 siswa 4 orang menjawab ya'dan 18 orang menjawab tidak, pembelajaran Discovery Learning membuat proses pembelajaran PPKn jadi menyenangkan dari 22 siswa 18 menjawab ya'dan 4 orang menjawab tidak,pembelajaran menggunakan Discovery Learning mudah di terimah di bandingkan dengan media lainnya dari 22 siswa 15 orang menjawab ya'dan 7 orang menjawab tidak,anda menyukai pembelajaran PPKn berbasis Discovery Learning dari 22 siswa 18 orang menjawab ya'dan 4 orang menjawab tidak,mempelajari PPKn menggunakan Discovery Learning memudahkan anda di bandingkan dengan pembelajaran konvensional dari 22 siswa 15 orang menjawab ya'dan 7 orang menjawab tidak.

Berdasarkan hasil penelitian mengenai pembelajaran berbasis Discovery Learning dalam pembelajaran PPKn dapat diketahui bahwa dengan model discovery Learning terjadi perubahan pada siswa dikelas pada saat pembelajaran PPKn berlansung siswa meperhatikan guru pada saat memberikan tujuan pebelajaran dan siswa aktif di dalam kelas pada saat guru memberikan stimulus kepada siswa. Berdasarkan hasil yang di dapat selama penelitian, penerapan model Discovery Learning pada mata pelajaran Pendidikan Pancasila dan kewarganegaraan di kelas X IPA SMA Batara Gowa dapat memberikan hasil yang cukup optimal serta sesuai dengan yang diinginkan. Pengaruh model Discovery Learning pada mata pelajaran Pendidikan Pancasila dan Kewarganegaraan di kelas $X$ IPA SMA Batara Gowa ini menunjukkan perubahan yang baik dalam meningkatkan hasil belajar serta dapat memberikan pemanfaatan kepada pihak sekolah untuk dapat memaksimalkan penggunaan model Discovery Learning.

\section{KESIMPULAN}

Dari pembahasan dan hasil penelitian dapat disimpulkan bahwa melalui model pembelajaran Discovery Learning terdapat pengaruh terhadap hasil belajar Siswa PPKn SMA Batara Gowa. Hal ini dibuktikan sebelum menggunakan model pembelajaran Discovery Learning hasil belajar siswa terlebih dahulu diberi perlakuan Pretest mata pelajaran PPKn untuk menguji hasil belajar siswa setelah di terapkan model pembelajaran Discovery Learning ,kemudian diberi perlakuan Posttest mata pelajaran PPKn untuk mengetahui hasil belajar siswa kelas X SMA Batara Gowa.

\section{DAFTAR PUSTAKA}

[1] Alma, Buchari, dkk. (2010). Guru Profesional Menguasai Metode dan Terampil Mengajar. Bandung: Penerbit Alfabeta.

[2] Ade Rukmana. (2006). Pengelolaan kelas dan Berbagai Faktor yang mempengaruhi. Jakarta: Remaja

[3] Arends, Richard. (2008). Learning to Teach. Yogyakarta: Pustaka Pelajar.

[4] Abdul Aziz Wahab. (2011). Pendidikan Kewarganegaraan. Bandung. Alfabeta

[5] Azra.Azyumardi. (2005). Pendidikan Kewarganegaraan Untuk demokrasi Indonesia. Jurnal ilmu-ilmu social UNISA. No. 57/XXVIII/2005

[6] Azra, A. (2005). Pendidikan Kewarganegaraan, Demokrasi HAM, dan Mayarakat madani. Tim ICCE UIN Jakarta : Prenada Media.

[7] Budimansyah, D. dan Komalasari. "Pengaruh pembelajaran Kontekstual dalam Pendidikan Kewarganegaraan".dalam Jurnal UPI Bandung

[8] Branson, M. S. (1999). Belajar"Civic Education"dari Amerika(Terjamahan Syarifuddin dkk). Yogyakarta: LKS.

[9] Campbell,D.T.,Stanley, J. C. Experimental \& Quasi Experimental Design For Researc. Kalangan Sendiri

[10] Cholisin, dkk. (2007). Ilmu Kewarganegaraan. Jakarta: Universitas Terbuka

[11] Depdiknas. (2006). Permendiknas No 22 Tahun 2006 Tentang Standar isi Jakarta: Depdiknas 
[12] E. Mulyasa. (2008). Menjadi Guru Propesional Menciptakan Pembelajaran Kreatif dan Menyenangkan. Bandung : PT. Remaja Rosdakarya.

[13] Hamalik. (2006). Proses Belajar mengajar. Bandung: Sinar Grafika

[14] Hanafiah. Nanang. Dan Cucu, Suhana, (2009). Konsep Strategi Pembelajaran. Pt Refika aditama. Bandung

[15] Kunandar.(2007).Guru Profesional.Implementasi kurikulum Tingkat satuan pendidikan (KTSP) dan Sukses dalam Sertifikasi Guru.Jakarta: Rajagrafindo Persada

[16] Mulyasa. (2008). Menjadi guru Profesional. Bandung. PT. Remaja Rosdakarya

[17] Kemendikbud (2013). Kementrian Pendidikan dan Kebudayaan tahun 2013 tentang Kriteria Hasil Belajar

[18] Riyanto, Yasin. (2010). Pradigma Baru Pembelajaran 2. Jakarta: Kencana Prenada Media Group

[19] Suciati, dkk. (2007). Belajar dan Pembelajaran 2. Jakarta: UnVersitas terbuka.

[20] Sudjana. (2001). Penilaian Hasil Proses Belajar Mengajar. Bandung: PT Remaja Rosdakarya

[1] Soemantri. (2001). Mengagas Pembelajaran Pendidikan. Bandung : Remaja Rosda Karya

[21] Sahabuddin. (1999). Mengajar dan Belajar. Ujung Pandang : Badan Penerbit Universitas Negeri Makassar

[22] Sugiyono. (2010). Statistika Untuk Penelitian. Bandung: Alfabeta

[23] Sugiyono. (2012). Metode Penelitian Kuantitatif dan R\&D. Bandung: Alfabeta

[24] Suprijono, Agus. (2010). Cooperative Learning. Yogyakarta: Pustaka Pelajar.

[25] Suryosubroto, B. (2009). Proses Belajar Mengajar di Sekolah. Jakarta: Rineka Cipta.

[26] Sutrisno, Joko. (2008). Pengaruh Metode Pembelajaran Inquiry dalam Belajar Sains terhadap Motivasi Belajar Siswa. http://www.erlangga.co.id. (Diunduh pada Tanggal 4 September 2014).

[27] Samsuri. (2008). Pengembangan Kewarganegaraan Sebagai Wahana Membangun Karakter Warga Negara. Tidak diterbitkan

[28] Sutrisno Hadi,dalam Sugiyono, (2012). Metode Penelitian Pendahuluan. Alfabeta, Bandung.

[29] Suardi, S. (2018). Penerapan Model Pembelajaran Saintifik Approacd Berbasis Media Pembelajaran Kearifan Lokal pada Mata Kuliah Dasar-Dasar Sosiologi dalam Membangun Karakter dan Meningkatkan Hasil Belajar Mahasiswa Pendidikan Sosiologi Universitas Muhammadiyah Makassar.Jurnal Etika Demokrasi Prodi PPKn Unismuh Makassar, 3(2).

[30] Suardi, S. (2018). Penerapan Model Pembelajaran Saintifik Approacd Berbasis Media Pembelajaran Kearifan Lokal pada Mata Kuliah Dasar-Dasar Sosiologi dalam Membangun Karakter dan
Meningkatkan Hasil Belajar Mahasiswa Pendidikan Sosiologi Universitas Muhammadiyah Makassar.Jurnal Etika Demokrasi Prodi PPKn Unismuh Makassar, 3(2).

[31] Suardi, S., \& Kanji, H. (2018). Lecture Model of Student Transfer Discussion Method to Increase Student's Activeness and Learning Outcomes.Journal of Educational Science and Technology (EST), 4(1), 48-54

[29] Trianto, (2010). Mendesain Model Pembajaran Inovatif, Progesif. Jakarta: Kencana

[30] Yamin, Martinis, (2007). Profesionalisasi guru \& Implementasi KTSP. Jakarta: Gaung Persada Press

[31] Zamroni (Tim ICCE, 2005:7) Pendidikan Kewarganegaraan : Perpustakaan 